\title{
Manchester Triage System (MTS): A REVIEW
}

\author{
Joko Tri Atmojo ${ }^{1}$, Rejo ${ }^{1}$, Sri Iswahyuni ${ }^{1}$, Aris Widiyanto ${ }^{1}$, Aquartuti Tri \\ Darmayanti $^{2}$ \\ ${ }^{1}$ STIKES Mamba'ul 'Ulum Surakarta \\ ${ }^{2}$ Program Magister Kesehatan Masyarakat, Universitas Sebelas Maret \\ (jokotriatmojo1@gmail.com)
}

\begin{abstract}
ABSTRAK
Latar Belakang: Triase adalah sistem manajemen risiko klinis yang digunakan pada unit gawat darurat di seluruh rumah sakit tempat pelayanan kesehatan di dunia. Manchester Triage System (MTS) adalah sistem klasifikasi prediksi prioritas dan risiko untuk pasien yang mencari perawatan darurat dan banyak digunakan di negara Uni Eropa. Perspektif teoretis dan sistematis telah dibahas penggunaan MTS pada unit gawat darurat sangat relevan, namun pemahaman dan penerapan triase ini di Indonesia masih belum baik, dengan demikian tujuan review ini adalah untuk membahas mengenai Manchester Triage System (MTS).

Tujuan: Tujuan review ini adalah untuk membahas mengenai Manchester Triage System (MTS).

Metode: Review ini dilakukan penulis dengan menelusuri database diantaranya PubMed, EMBASE, dan CINAHL. Kata kunci yang digunakan: 'Triage in emergency 'ATAU' 'Manchester Triage Scale' ATAU Manchester protocol" ATAU "Manchester System" ATAU "Manchester risk assessment". Penelusuran ini dilakukan mulai dari Agustus hingga September 2019, kriteria artikel adalah: uji acak terkendali (randomized controlled trial), studi retrospektif, observasional, studi kasus, review, systematc review, dan meta analisis.

Hasil: Metode MTS dirancang untuk memungkinkan praktisi kesehatan pada unit gawat darurat untuk secara cepat menetapkan prioritas klinis untuk setiap pasien dengan 5 langkah yang mengedepankan penilaian rasa sakit atau nyeri. MTS dilaporkan memiliki reliabilitas sedang dan efikasi yang dapat mendukung penerapan MTS. MTS juga telah terbukti valid untuk digunakan pada anak-anak dan orang dewasa dengan sindrom koroner dan pasien dengan emboli paru akut. MTS ditemukan inklusif untuk memprediksi penerimaan gawat darurat dan kematian dalam jangka pendek
\end{abstract}

Simpulan: Bukti ilmiah menunjukan tingkat keandalan MTS dapat diterima bila diterapkan pada unit gawat darurat,

Kata Kunci: Triase, Manchester Triage System, Review, MTS

\section{ABSTRACT}

Background:Triage is a clinical risk management system that is used in emergency departments throughout hospitals in the world. Manchester Triage System (MTS) is a priority and risk prediction classification system for patients seeking emergency care and is widely used in European Union countries. The

Manchester Triage System (MTS): A REVIEW (Joko Tri Atmojo, Rejo, Sri Iswahyuni, Aris Widiyanto, Aquartuti Tri Darmayanti) 
theoretical and systematic perspectives discussed about the use of MTS in the emergency department are very relevant, but the understanding and application of this triage in Indonesia is still not good. Thus, the purpose of this review is to discuss the Manchester Triage System (MTS).

The Purpose: This study aims to review the Manchester Triage System (MTS).

Method: This review was conducted by the author by searching databases including PubMed, EMBASE, and CINAHL. Keywords used: 'Triage in emergency' OR 'Manchester Triage Scale' OR Manchester protocol "OR" Manchester System "OR" Manchester risk assessment ". This search was conducted from August to September 2019, the criteria of the article were: randomized controlled trials, retrospective, observational studies, case studies, reviews, systemic reviews, and meta-analyzes.

Results: The MTS method was designed to enable healthcare practitioners in the emergency department to quickly establish clinical priorities for each patient with 5 steps that put forward the assessment of pain or pain. MTS is reported to have moderate reliability and efficacy that can support the application of MTS. MTS has also been proven valid for use in children and adults with coronary syndrome and patients with acute pulmonary embolism. MTS was found to be inclusive to predict emergency admission and death in the short term

Conclusion: Scientific evidence shows that the level of reliability of MTS is acceptable when applied to emergency departments,

Keywords: Triase, Manchester Triage System, Review, MTS

\section{PENDAHULUAN}

Triase adalah sistem manajemen risiko klinis yang digunakan pada unit gawat darurat di seluruh rumah sakit tempat pelayanan kesehatan di dunia untuk mengelola aliran pasien dengan aman saat dibutuhkan secara klinis. Sistem dimaksudkan untuk memastikan perawatan sesuai untuk kebutuhan pasien dan tepat waktu. Triase juga merupakan bagian mendasar dari manajemen risiko klinis ketika beban klinis melebihi ketersediaan klinis (Manchester triage group, 2013).

Triage telah muncul sebagai metode untuk mengoptimalkan kehadiran, dan untuk meminimalkan kerusakan yang disebabkan oleh kepadatan, karena jumlah pasien yang datang ke unit gawat darurat terus meningkat dan tidak dapat diprediksi dengan akurat, mulai dari yang memiliki masalah klinis tinggi ataupun ringan, sehingga sering terjadi masalah organisasi sebagai contoh hanya sebagian pasien memiliki kondisi yang membahayakan jiwa atau darurat medis dan tidak semua yang dirawat di ruang gawat darurat dapat dirawat di rumah sakit yang sama. Dengan demikian pasien diklasifikasikan menurut keparahan klinis, tingkat penderitaan dan risiko terhadap kesehatan mereka sendiri. Dengan cara ini, triase didefinisikan sebagai proses klasifikasi pasien yang dinamis yang memungkinkan pasien untuk dialokasikan ke layanan perawatan yang paling cocok dengan lebih cepat (Ganley dan Gloster, 2011; Azeredo et al., 2014; Atmojo et al, 2019).

Di seluruh dunia, berbagai skala triase digunakan di departemen gawat darurat karena perbedaan fungsional dalam layanan. Namun tetap ada kebutuhan untuk 
itu skala triase yang seragam dan cocok digunakan pada semua layanan (Christ et al.,2010). Tidak ada instrumen pengukuran yang sempurna, karena kesalahan dapat timbul karena faktor pribadi, situasi lingkungan, perubahan dalam metode pengumpulan data dan proses adaptasi (Souza et al., 2017; Azeredo et al., 2014). Penerapan sistem triase harus mampu memprediksi tingkat keparahan penyakit, tingkat kematian, kebutuhan sumber daya, mudah dipahami, diterapkan dan memiliki kesamaan interobserver yang tinggi (Christ et al., 2010).

The Manchester Triage Group pertama kali didirikan pada bulan November 1994 dengan tujuan membangun konsensus antara perawat darurat senior dan dokter pada unit gawat darurat tentang standar triase. Tujuan dari The Manchester Triage adalah: (1) Mengembangkan nomenklatur bersama. (2) Mengembangkan definisi umum. (3) Mengembangkan metodologi triase yang kuat. (4) Mengembangkan paket pelatihan. (5) Mengembangkan panduan audit untuk triase (Mirhaghi et al., 2017).

Manchester Triage System (MTS) adalah sistem klasifikasi prediksi prioritas dan risiko untuk pasien yang mencari perawatan darurat dan banyak digunakan di negara Uni Eropa (Storm-Versloot et al., 2011). MTS memiliki daftar 52 kondisi atau presentasi yang telah ditentukan diagram alur yang dikombinasikan dengan keluhan utama yang dilaporkan oleh pasien dan dicatat pada formulir oleh perawat. Klasifikasi tersebut dibagi menjadi lima warna: merah (langsung), oranye (sangat mendesak), kuning (mendesak), hijau (standar) dan biru (tidak mendesak) (Speake et al., 2003).

Perspektif teoretis dan sistematis telah dibahas penggunaan MTS pada unit gawat darurat sangat relevan, karena MTS telah diperkenalkan ke dalam praktik triase gawat darurat belum lama ini. Sehingga hal ini akan meningkatkan pemahaman tentang sistem triase ini dan menunjukkan indikasi ilmiah untuk implementasinya dalam konteks sosial yang berbeda, namun pemahaman dan penerapan triase ini di Indonesia masih belum baik. Dengan demikian, tujuan review ini adalah untuk membahas mengenai Manchester Triage System (MTS).

\section{METODE PENELITIAN}

Review ini dilakukan penulis dengan menelusuri database diantaranya PubMed, EMBASE, dan CINAHL untuk mengetahui potensi studi yang memenuhi syarat. Kata kunci yang digunakan antara lain: 'Triage in emergency 'ATAU' 'Manchester Triage Scale' ATAU Manchester protocol" ATAU "Manchester System" ATAU "Manchester risk assessment".

Penelusuran ini dilakukan mulai dari Agustus hingga September 2019, kriteria artikel yang masuk dalam review kali ini adalah: uji acak terkendali (randomized controlled trial), studi retrospektif, observasional, studi kasus, review, systematic review, dan meta analisis. Artikel akan di eksklusi jika mereka menggunakan skala ini sebagai variabel penjelas, jika mereka fokus pada spektrum terbatas dari penyakit dan gejala atau populasi yang diklasifikasikan dalam batas tertentu tanpa alasan yang jelas. 


\section{HASIL DAN PEMBAHASAN}

\section{Metode MTS}

Metode MTS dirancang untuk memungkinkan praktisi kesehatan pada unit gawat darurat untuk secara cepat menetapkan prioritas klinis untuk setiap pasien, adapun 5 langkah yang perlu dilakukan antara lain:

1 Identifikasi masalahnya

2 Kumpulkan dan analisis informasi yang terkait dengan solusi

3 Evaluasi semua alternatif dan pilih satu untuk implementasi

4 Terapkan alternatif yang dipilih

5 Pantau implementasi dan evaluasi hasil

(Manchester triage group, 2013).

2. Penilaian rasa sakit/nyeri sebagai bagian dari proses triase

Rasa sakit atau nyeri adalah masalah utama bagi pasien yang datang ke unit gawat darurat. Penilaian rasa sakit harus tetap dilakukan diawal metode triase sehingga dapat dikelola dengan tepat. Hal ini dikarenakan beberapa alasan berikut:

1 Tingkat rasa sakit memengaruhi urgensi

2 Keberhasilan manajemen nyeri adalah kriteria utama untuk kepuasan pasien

3 Pasien yang sakit bisa menjadi gelisah dan agresif

4 Pasien yang sakit adalah sumber kesusahan dan stres bagi tenaga kesehatan dan pasien lain

5 Pasien selalu memiliki harapan bahwa rasa sakit mereka akan ditangani

Pengurangan rasa sakit dapat menyebabkan pengkategorian ulang ke tingkat yang lebih rendah prioritas. Berkurangnya kecemasan pasien akan meningkatkan komunikasi. Tanpa penilaian nyeri, pemberian analgesia yang tepat pada triase itu tidak mungkin. Ada tiga jenis utama alat penilaian nyeri yaitu : Verbal descriptor scales, Visual analogue scales, Pain behaviour tools (Manchester triage group, 2013).

\section{Reliabilitas MTS}

Reliabilitas dari skala MTS pada populasi orang dewasa dan anak-anak telah dilaporkan memiliki konsistensi sedang (Andersson et al., 2006). Studi meta analisis yang dilakukan Mirhaghi et al., 2017 melaporkan bahwa terdapat tujuh studi yang memberikan kesimpulan reliabilitas MTS secara substansial pada 0,751 (CI 95\%: 0,677 hingga 0,810); insiden kesalahan lebih besar dari 50\%. Reliabilitas lebih tinggi dilaporkan untuk versi MTS terbaru (untuk orang dewasa) di negara-negara yang lebih dekat ke negara asal MTS (Inggris, di Manchester) daripada untuk versi (pediatrik). Insiden kesalahan lebih besar dari $50 \%$. Sehingga dapat disimpulkan MTS menunjukkan tingkat keandalan yang dapat diterima apabila diterapkan di pelayanan gawat darurat (Atmojo et al, 2019). 


\section{Efikasi MTS}

Sebuah stusi systematic review yang dilaporkan oleh (Azeredo et al., 2014) menyatakan mendukung penerapan MTS, yang telah terbukti valid untuk digunakan pada anak-anak, orang dewasa, pasien dengan sindrom koroner dan pasien dengan emboli paru akut. MTS ditemukan inklusif untuk memprediksi penerimaan gawat darurat dan kematian dalam jangka pendek.

Dua dari 22 studi dalam review tersebut tidak melaporkan efikasi yang tinggi untuk MTS. Studi-studi ini menemukan bahwa efikasi MTS tergolong tinggi pada pasien dengan sindrom koroner akut (Trigo et al., 2008), dan MTS tidak memprediksi adanya infeksi bakteri parah pada anak-anak yang datang ke unit gawat darurat (Nijman et al., 2011).

\section{SIMPULAN DAN SARAN}

\section{Simpulan}

Manchester Triage System (MTS) adalah lima tingkat algoritma triase gawat darurat yang terus dikembangkan di Inggris dan diadopsi oleh beberapa negara. Mayoritas penelitian menemukan bahwa MTS berguna dalam triase pasien di unit gawat darurat dengan tingkat reliabilitas sedang. MTS menunjukkan tingkat keandalan keseluruhan yang dapat diterima di

departemen darurat, tetapi pengembangan lebih lanjut diperlukan untuk mencapai kesepakatan yang sempurna.

\section{Saran}

Bagi tenaga kesehatan pada unit gawat darurat MTS tidak diragukan lagi telah digunakan untuk membantu pengklasifikasian pasien. Namun harus selalu diingat bahwa utilitas apa pun di dalam proses selain ini harus dibuktikan daripada diasumsikan. Sehingga peluang untuk para akademisi kesehatan dalam mengembangkan dan mempraktikkan MTS masih sangat terbuka lebar.

\section{DAFTAR PUSTAKA}

Andersson, A. K., Omberg, M. and Svedlund, M. (2006) 'Triage in the emergency department--a qualitative study of the factors which nurses consider when making decisions. ', Nursing in critical care.

Atmojo JT, Widiyanto A, T Yuniarti (2019). Reliabilitas sistem triase dalam pelayanan gawat darurat: A review. Jurnal Ilmu Keperawatan Intan Husada. Vol 7 No. 2

Azeredo, T. R. M. et al. (2014) 'Efficacy of the Manchester Triage System: a systematic review', International Emergency Nursing. Elsevier Ltd, 23(2), pp. 47-52.

Christ, M., Grossmann, F., Winter, D., Bingisser, R., Platz, E., 2010. Modern triage in the emergency department. Deutsches Ärzteblatt International. 107, 892-898.

Ganley, L., Gloster, A., 2011. An overview of triage in the emergency department. Nursing Standard. 26, 49-57. 
Manchester Tria e Gro u p. (2013). Manchester Tr i a ge Gro u p. Third Edition

Mirhaghi, A. et al. (2017) 'The reliability of the Manchester Triage System (MTS): a meta-analysis', Journal of Evidence-Based Medicine, 10(2), pp. 129-135.

Nijman, R.G., Zwinkels, R.L., van Veen, M., Steyerberg, E.W., van der Lei, J., Moll, H.A., et al., 2011. Can urgency classification of the Manchester triage system predict serious bacterial infections in febrile children? Archives of Disease in Childhood. 96, 715-722.

Souza, C. C. de et al. (2017) 'Risk classification in an emergency room: agreement level between a Brazilian institutional and the Manchester Protocol', Revista Latino-Americana de Enfermagem.

Speake, D., Teece, S., Mackway-Jones, K., 2003. Detecting high-risk patients with chest pain. Emergency Nurse. 11, 19-21.

Storm-Versloot, M.N., Ubbink, D.T., Kappelhof, J., Luitse, J.S.K., 2011. Comparison of informally structured triage system, the Emergency Severity Index, and the Manchester Triage System to distinguish patient priority in the emergency department. Academic Emergency Medicine. 18, 822-829.

Trigo, J., Gago, P., Mimoso, J., Santos, W., Marques, N., Gomes, V., 2008. Inhospital delay ST-segment-elevationmyocardial infarction after Manchester triage. Revista Portuguesa de Cardiologia. 27, 1251-1259. 